
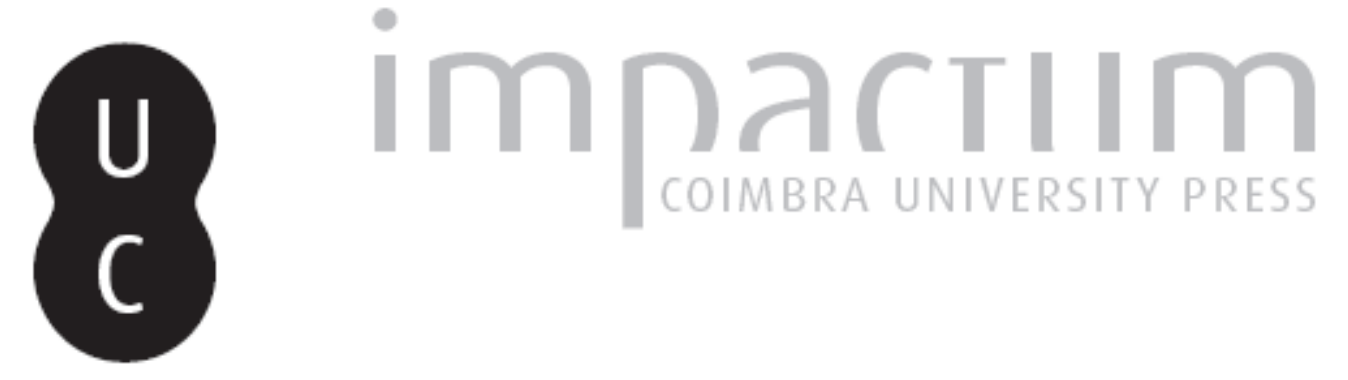

\title{
Summer houses, ruin, demolition and rehabilitation: Modern Architecture heritage between 1950 and 1960 in Portugal
}

Autor(es): $\quad$ Freitas, Tiago

Publicado por: Editorial do Departamento de Arquitetura

URL persistente:

URI:http://hdl.handle.net/10316.2/39959

DOI:

DOI:https://doi.org/10.14195/1647-8681_6_24

Accessed : $\quad$ 26-Apr-2023 11:39:45

A navegação consulta e descarregamento dos títulos inseridos nas Bibliotecas Digitais UC Digitalis, UC Pombalina e UC Impactum, pressupõem a aceitação plena e sem reservas dos Termos e Condições de Uso destas Bibliotecas Digitais, disponíveis em https://digitalis.uc.pt/pt-pt/termos.

Conforme exposto nos referidos Termos e Condições de Uso, o descarregamento de títulos de acesso restrito requer uma licença válida de autorização devendo o utilizador aceder ao(s) documento(s) a partir de um endereço de IP da instituição detentora da supramencionada licença.

Ao utilizador é apenas permitido o descarregamento para uso pessoal, pelo que o emprego do(s) título(s) descarregado(s) para outro fim, designadamente comercial, carece de autorização do respetivo autor ou editor da obra.

Na medida em que todas as obras da UC Digitalis se encontram protegidas pelo Código do Direito de Autor e Direitos Conexos e demais legislação aplicável, toda a cópia, parcial ou total, deste documento, nos casos em que é legalmente admitida, deverá conter ou fazer-se acompanhar por este aviso.

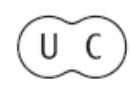




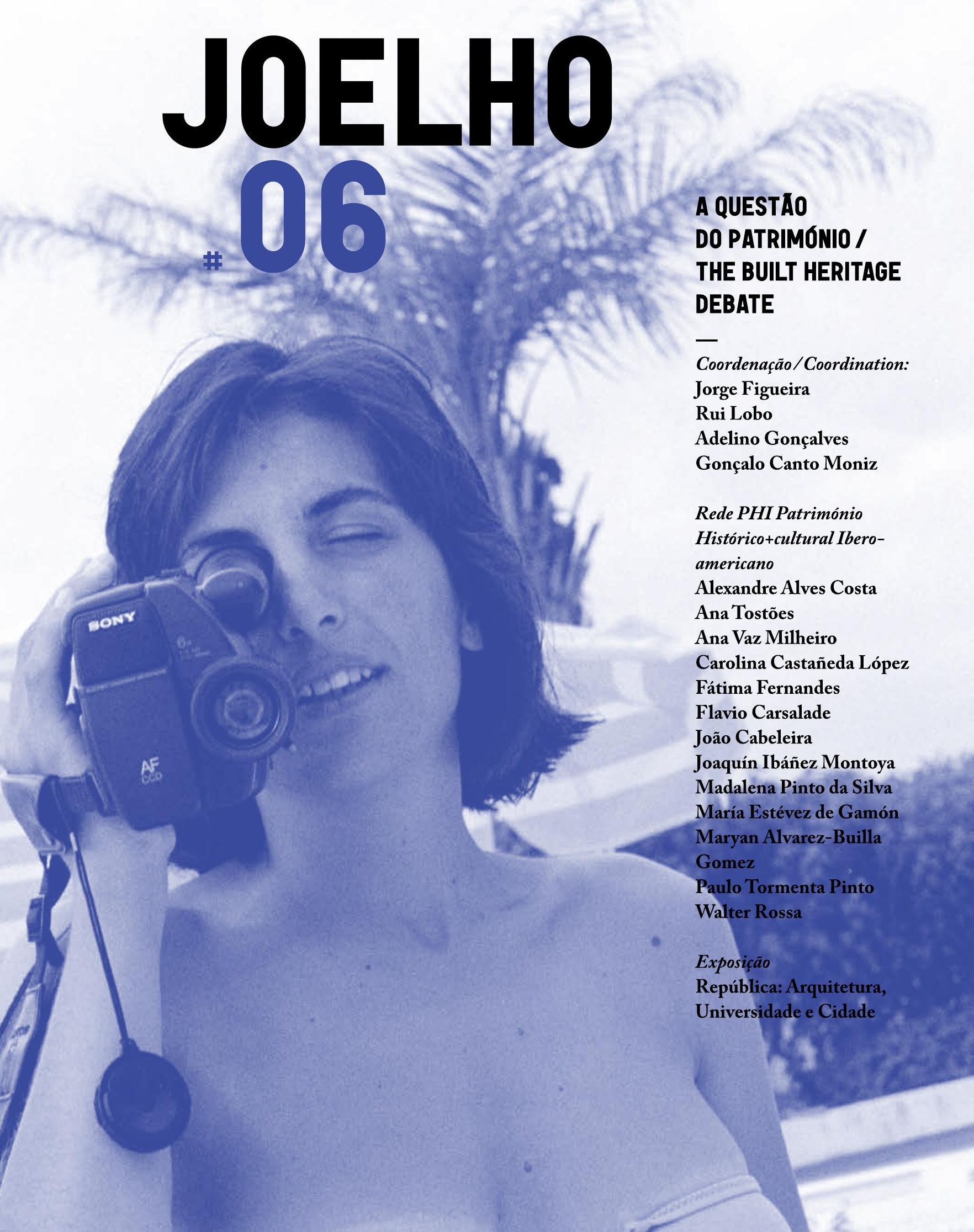




\section{Tiago Freitas \\ Summer I-Iouses, Ruin, \\ Demolition and Rehabilititation: Modern Architecture heritage between 1950 and 1960 in Portugal}

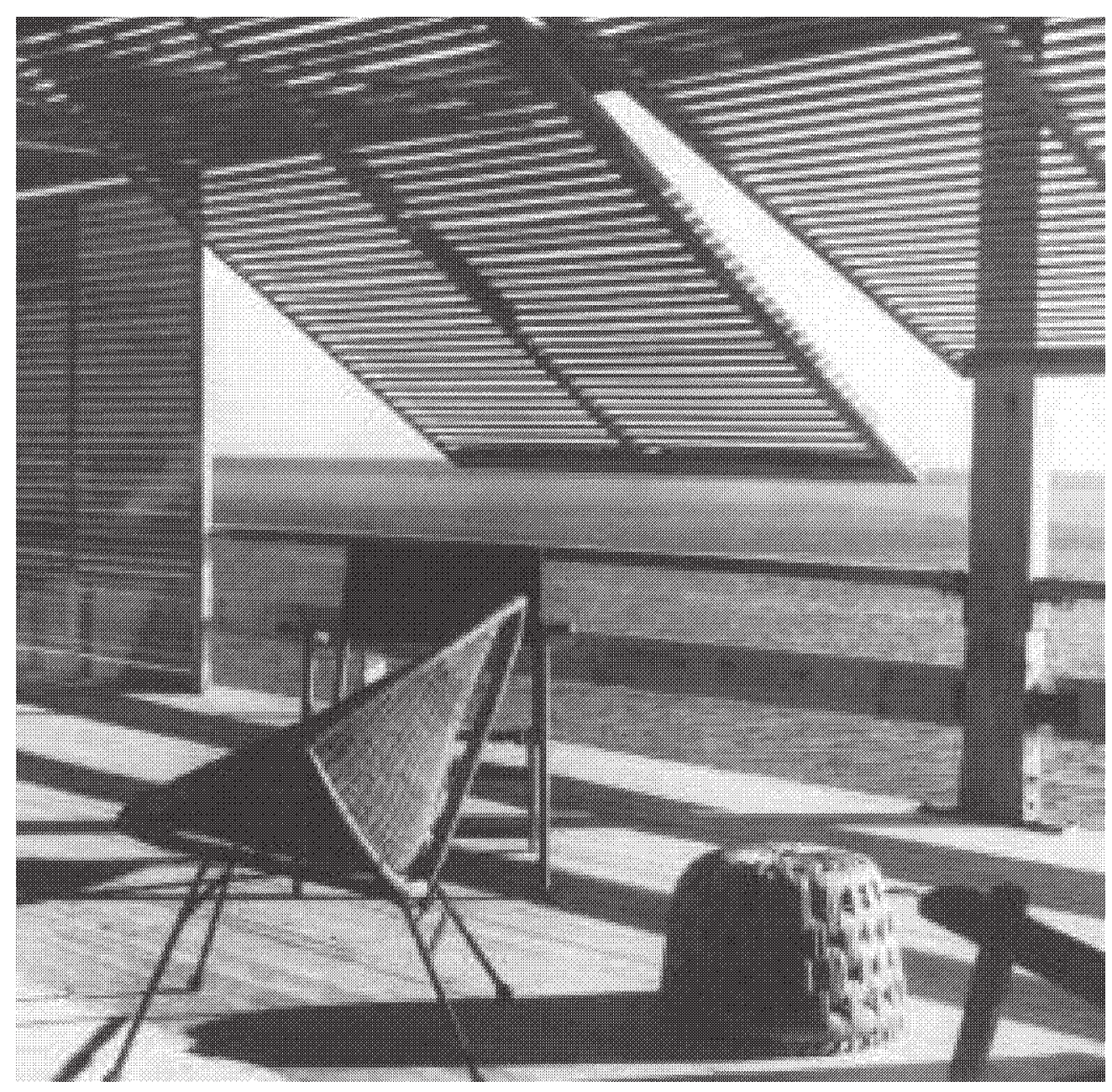




\section{INTRODUCTION}

The search for a new architectural model for the holiday house derived from the chalet begins in Portugal in the decades of 1930/1940. It is this house, originating predominantly in the decades of 1950/60 that will imprint a new acceptance for the modern movement in Portugal.

Until now, these holiday houses have resisted as built heritage from the 40's decades. As holiday houses they are normally closed for most of the year and open for the vacation period; their property is normally divided between several owners dew to inheritances, originating legal problems due to the division of property. As a consequence, some are put on sale or persist until decay and eventual ruin. Others can't avoid being demolished or replaced by new refurbishments which transform them into more up to date edifications; Frequently, their second or third owners have little (bar none) awareness of their original architectural characteristics. It is important to understand how this modern heritage can adapt to modern life requirements. According to Marieke Kupiers (2005) this is almost an impossible mission “(...) to restore an icon of the modern movement without changes, of materials, functions or forms, is a mission impossible, especially if one wants to keep the building alive (...)" (Kupiers, 2005, p.209).

The main objective of this investigation is to find out the architectural expressions contained in these houses, promoting the (re)cognition of exemplary models of modern holiday houses in Portugal, some still unknown. Mapping, registering and analysing this architectural production will help us understand the implications for Portuguese culture and art, as well as the innovations which were implemented in this period.

The investigation focuses on four case studies of modern architecture. Two examples of ruin and demolition, Aiola and José Soares house; and two cases of rehabilitation of modern architecture, Marinhas and Ribeiro da Silva house, one which originated a house/museum and the other which was maintained as holiday house until today.

\section{HOLIDAY HOUSES IN PORTUGAL}

Tourism was the engine of urbanization and transformation of the Portuguese coastline in the twentieth century. To understand the phenomenon of global tourism (Cazes, 1992; Boyer, 1995), are two fundamental authors. The approach of the touristic phenomena is made by a contextualization in the late eighteenth century towards the beginning of the twentieth century. The escape from the cities, and the search for the health benefits which can be found at the "seaside" was predominantly led by an elite composed mainly of Aristocracy and Bourgeoisie.

In England, Brighton or Bournemouth emerged as two seaside resorts in this period. The holiday houses that are built at these resorts are composed initially as Roman villae, transformed into Palladian buildings in the Renaissance and, later, into chalets. According to Rui Ramos 
(2010), “(...) This house comes as a synthesis between the Farm House and the recreational or vacation home of the upper classes, initially designed as cottage orné, characterized by the use of rustic materials and asymmetrical compositions (...)" (Ramos, 2010, p.78).

In Portugal, (Briz, 2003; Lobo, 2012), trace the uprising of the touristic phenomena. The nineteenth century is characterized by a period of pretourism. Sintra becomes the ideal place for the construction of chalets with eclectic manifestations impressed with a romantic taste. Cascais or the Granja, and later the Estoril, will be the seaside resorts of Portugal between 1865 and the 1930s. From the decades of 1930/1940, the search for a new architectural model of holiday house derived from the chalet begins. According to Ana Tostões (2000) “(...) the end of the war, with the awakening of the democracy and a reinvigorated opposition by the defeat of fascism in Europe, draws a time of cultural upheaval which makes the end of the 4OS a particularly moment in the reflection of modern architecture in Portugal (...)" (Tostões, 2000, p.45).

Several authors, (Fernandez, 1988; Tostões, 1997; Ramos, 2010) produce a wise reflection of the architectural production of this period. The single-family house and consequently the holiday house will be assumed as a research laboratory for many architects, exploring new typologies, materials and construction techniques which will posteriorly be applied as industrial processes in the construction of collective housing. The objects of this investigation are the holiday houses built in Portugal during the decades of 1950 and 1960. Since 1974 and with the end of the dictatorship period in Portugal, another type of tourism developed, more commonly known as mass tourism. This tourism will use collective housing as its main development and will be promoted by economic speculation.

\section{CASE STUDIES}

House Aiola, Eduardo Anahory, Arrábida, 1960 (demolished). House Aiola was located in Arrábida, in a cliff overlooking the sea. The house was a work of unquestionable modern taste, influenced by the experiments of the American architect Craig Elwood.

Eduardo Anahory was a designer based in Lisbon who decided to build a holiday house in Arrábida for his family. As the designer referred, to the magazine Binário (1963), “(...) not allowed to work with masonry because of the regulations for the area, he was obliged to seek firm rocks and implement a structure in steel and wood hanging over the cliff (...)" ${ }^{1}$.

The internal organization of the house, in perfect communion with the exterior, is very fluid. The terrace is in direct relationship with the living area and creates one common space. Two bedrooms, one kitchen and two toilets organize the plan. This private area of the house divides the rectangular plan and articulates itself with a private terrace. Modern materials and prefabricated construction methods are used 


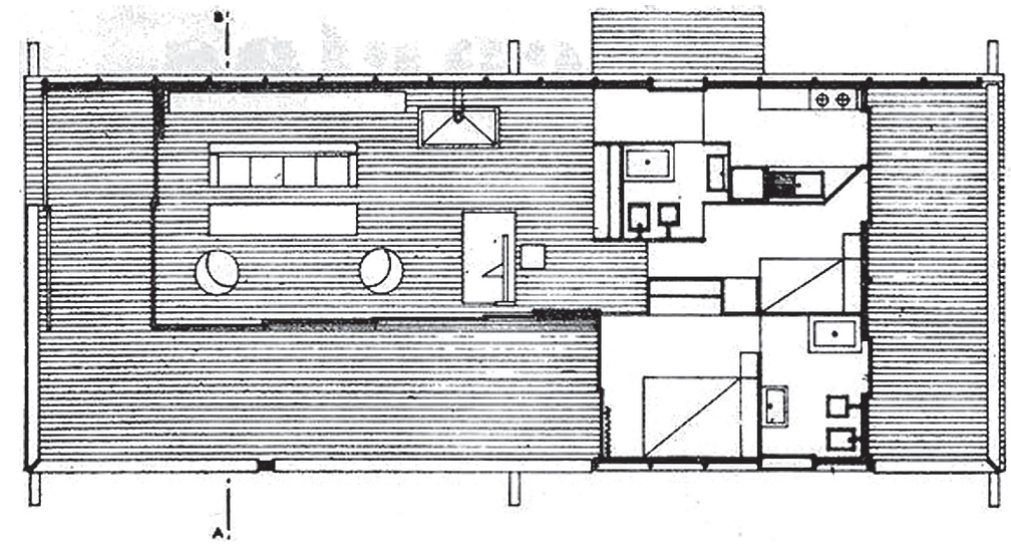

1. House Aiola: Plan. (Fonte: Binário, "Casa de férias, Arrábida" Lisboa, №59, Maio 1963, pp.481.)

at Aiola. Plastic tiles are used for the pavement of the kitchen and bathrooms, the walls are made of panels of agglomerated cork coated in mutene plywood, the bathrooms and kitchen use laminated plastic. Doors and windows have similar technical systems to boats, manifested namely by the use of rope cables.

The use of new materials, such as plywood and wood panels, makes this house an authentic modern laboratory. According to Rui Ramos (2010) “(...) the house reveals an unconditional adoption of modern, being able to innovate on the constraints imposed on it. The quality of this house and the uniqueness of this work transform this house on one of the most radically modern examples that was built in Portugal (...)" (Ramos, 2010, p.521), yet virtually unknown and demolished.

\section{House José Soares, Arménio Losa, Cassiano Barbosa, Ofir, 1950.}

The José Soares house in Ofir is a virtually unknown work of the modern Portuguese architects located in the summer resort of Ofir. Ofir is a northern resort where other important summer houses were built predominately between the decades of 1940 and 1970.

The organization of the house is made in a standardized way, dividing the areas in functional zones with a $\mathrm{T}$ form plan.

Having a rather vast program for a summer house, the $\mathrm{T}$ shape plan is divided in sleeping (with five bedrooms and toilets), living (with a big common living room divided in two floors) and services (with kitchen, maid's rooms and toilet). This organization is clearly an adoption of the modern principles, "there is an accurate translation of the three functional groups (rooms, services and living room) in three spatially differentiated interior areas and exterior volumes that show this structure" (Ramos, 2010, p.358-359). The house is slightly elevated in pilotis, originating a ramp that makes the access to the main entrance. This ramp, situated in an oblique angle, creates a promenade architectural when coming inside the house. To complement this promenade, the architects decorated one of the confronting facades

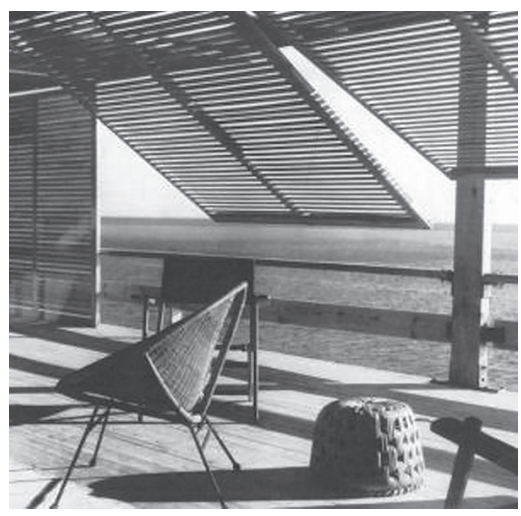

2. House Aiola: Living room/terrace overlooking the sea. (Fonte: Binário, "Casa de férias, Arrábida" Lisboa, N59, Maio 1963, pp.480.) 


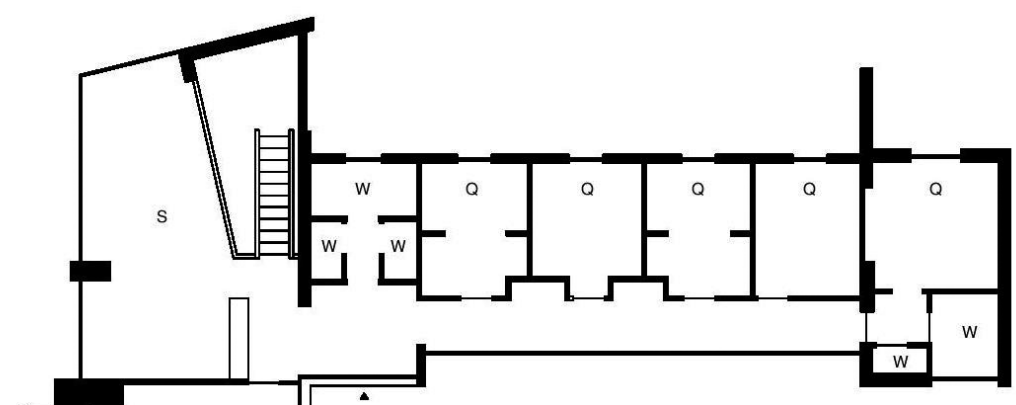

with a decorative painting made in tiles. This facade is completely enclosed, having an upper longitudinal opening, which illuminates the interior corridor. This corridor gives access to the five bedrooms. The pillars that elevate the house stand apart from this façade creating a colonnade. The living area is assumed as the main core of the house. Divided in two floors, it establishes visual connection with

3. José Soares House: Upper floor plan (fonte: Freitas, Tiago, plan redesigned by the author, using the original plan of the house submitted with courtesy by the Esposende town Hall, Porto, 2015.)

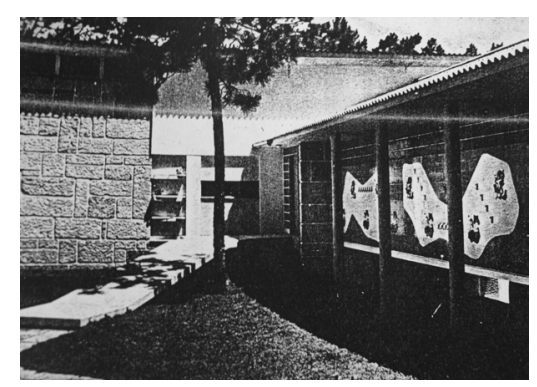

4. José Soares House: Entrance with access ramp and decorated façade (Fonte: Amorim, Fernandes; ODAM: Organização dos arquitectos modernos. Porto,1947-1952, Edições Asa, Porto, 1972.)

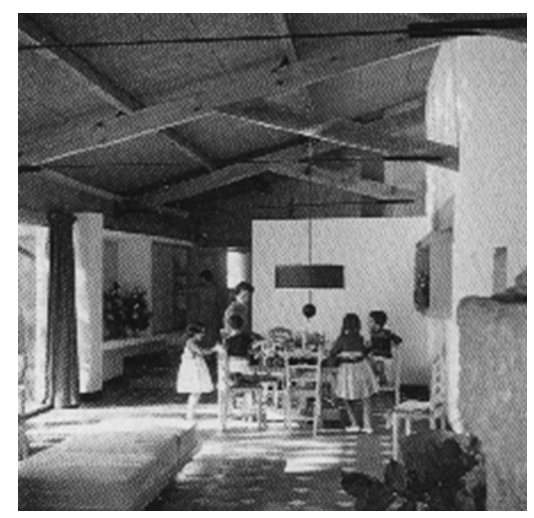

5. Ribeiro da Silva house: Living room (Fonte: Sousa, Rui Morais de, Fernando Távora, Blau, Lisboa, 1993.) the upper floor and the entrance. The service area is divided and makes a specialization of the functions, divided into kitchen, pantry, maid's room and toilet.

The materials which are used in the construction establish a contrast between the adaptations of modern industrial methods such as fibre cement undulated roofing and concrete slabs and traditional stone masonry walls, decorative tiling and wooden joinery.

The house, nowadays, reveals signs of being closed for years. The abandonment of the property makes it reach an advanced state of decay and eventually ruin.

\section{Ribeiro da Silva house, Fernando Távora, Ofir, 1957.}

Ribeiro da Silva house at Ofir is one of the most important holiday houses built in Portugal in the decade of 1950. Having been in advanced state of ruin for some years, the house has in the past months undergone a complete rehabilitation process.

The work was considered, in its time, by the magazine Arquitectura (1957), "(...) as a valid work, not only for the constructive sincerity as for the subdivision operation of human enhancement of internal and external environments. The exterior will be intensively involved in the domestic living area, the extension of the walls and the definition of the bodies of the house, shelter it from the main winds creating an exterior patio that is organized as an artificial dune in grass that makes limit of the plot facing the river (...)" ${ }^{2}$.

The house is divided in a completely modern and functional organization, assuming the T shape plan. Three clearly different areas are recognizable from the exterior: Services (with maid room, kitchen, pantry and garage) living (living room and entrance) and sleeping (five rooms and toilets). These areas establish relationships with the exterior and expand themselves towards natural patios. For the construction, Távora used traditional materials and construction techniques in contrast with modern ones. 
The traditional pitched roof, covered with clay tiles, is assumed. Wooden joinery in the windows and the roof trusses, natural stone pavements in the floors and granite stone walls painted in white, resemble the traditional houses of the region. To establish contrast, modern materials such as concrete are used in the roof slabs and the chimney. Agglomerated cork is used to cover the interiors of the roofs. Modern codes and concepts are visible in the abstract design of the openings, in the way the house is organized in different functional zones and in the standardized distribution of the sleeping areas.

The house will represent a big contrast between modern and vernacular, establishing a wise understanding of the Portuguese cultural traditions, albeit not putting apart the codes used by the modern movement. Ribeiro da Silva house stands as a milestone in the transition of modern architecture in Portugal, and was considered Monument in 2012. Nowadays it continues to be used as a holiday house.

\section{Marinhas house, Alfredo E. Viana de Lima, Marinhas, 1954.}

This holiday house, located in the village of Marinhas, near to the sea and to the city of Esposende, is a small modern essay where Viana de Lima assumes his unconditional obsession for Le Corbusier. Viana de Lima, the architect and owner of the house, decided to build a holiday house for his family in a plot with a ruin of an abandoned windmill.

The windmill will be the source of the entire project. “(...) the choice of the windmill as the primary concept, results once again as an illustration of a bucolic idea that was always present, perhaps in a subtle way in his career (...)"(Almeida, 1996, p.82). Decided to keep it, the architect organizes the house, establishing a contrast with the pre-existence.

The plan is divided in the pre-existence (windmill) and new pavilion connected by a corridor (passage). The windmill will function as the main access to the house and distributor element with the upper floor. The new pavilion, built as a rectangular box with flat roof, is organized in the ground floor with one big living area. This living room is divided by the use of fixed furniture, into dining, living and kitchen. The ground floor is very fluid and establishes visual contact with the upper floor through the two-story high ceiling. The upper floor, with two bedrooms, a study and a toilet is designed in a standardized way, resembling us the theories of the existenzminimum.

The introduction of traditional materials such as wooden joinery, granite stone walls or the pre-existing windmill in the new construction make a clear contrast with explicit references to the Modern Movement.

The house establishes a continuation and evolution of the Portuguese architecture of the 50s in Portugal. Opposed to the standardized architectural works of the modern period, it seeks a relationship with the place, the plot and its surroundings.

Having been donated by the architect in life to the University of Porto, it experienced a phase of abandonment and decay.

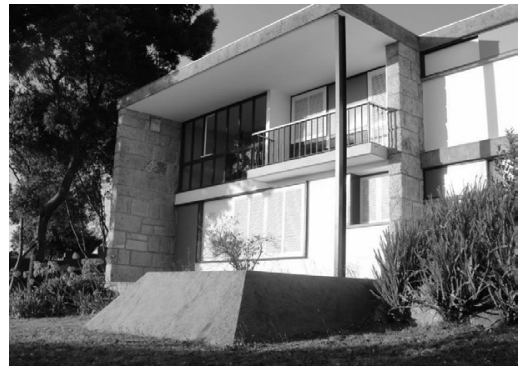

6. Marinhas house: West façade, new pavilion (Foto: Freitas, Tiago, Marinhas, 2013.) 
Considered a monument in 2012, the house is now open as a museum and is nowadays maintained in a perfect state of conservation.

Ruin, demolition or preservation of modern heritage?

\section{(...) the conservation of modern architecture is one of the two basic missions of D С ОМОМO International, the other being its documentation (...)}

(Vanlaethem, 2005, p.197)

These four case studies represent a small part of the vast group of modern holiday houses built in Portugal between the decades of 1950/60. Two represent the ruin and decay, one of them having originated to a fatal case of demolition; the other two represent cases of successful rehabilitation of modern heritage. It is not strange that the two modern cases of success are considered monuments. Is this the necessary condition for the correct preservation of modern legacy? According to France Vanlathem (2005) “(...) If progressively modern architecture is better protected within numerous countries, it is so more under the rubric of historical monument than heritage building. One must not confuse the two notions. The first classification, adapted in the 2oth century, depends upon the judgment of specialists and the appreciation of elite. The second, to the contrary, implicates wider approval and leads to an expansion and diversification within the domain of conservation (...)" (Valathem, 2005, p.198). It is important to think about what type of heritage we want to leave to the future generations, and about what we can do to preserve this legacy.

House Aiola was demolished due to the natural preservation of the beach. Is this a case of fundamentalism? Mass tourism and economic speculation destroyed natural settings in the decade of 1980 all through Portugal, predominately in the Algarve, as well, without having been demolished.

José Soares house is closed permanently and is arriving to an advanced state of decay. Are there owners aware of such unique modern example of architecture? Will it advance to ruin or face in time the property market, being put on sale? Will it be transformed to a more up to date refurbishment or persist as modern legacy?

Ribeiro da Silva house, suffered a big fire. The actual owners inherited a monument and had problems in solving the ownership of the property. As a consequence, the house reached a phase of ruin. Hopefully the owners were able to reach a solution for the property and restored it with absolute precision. Was this only possible for the classification of the house as a Monument?

Marinhas house, after having endured a period of neglect when in the possession of the University of Porto, was totally rehabilitated and now experiences a new era in the management of the Esposende town hall, having become the house museum of Viana de Lima. As 
Ribeiro da Silva house, the house was considered a monument from 2012 onwards. Was this only condition for its absolute maintenance?

According to Marieke Kupiers (2005) “(...) Private houses are better suited for conservation, not necessarily in the form of museum-house (...) the result always depends on the owners because they decide about the architect to be involved, aside from budget and degree of living standard (...)" (Kupiers, 2005, p.213).

\section{CONCLUSIONS}

The important models of modern holiday houses built between 1940 and 1974 in Portugal, in resorts from Rodizio in the South to Moledo do Minho in the North must be preserved. Most of these houses represent a legacy of the modern movement in Portugal. José Soares house in Ofir stands out as a perfect example, unknown of the general public. Owned by families for generations, they persist as the owners try to maintain their initial program of holiday houses. According to France Vanlathem (2005)“ (...) Can we not ask ourselves if the difficulty of modern architecture in imposing itself as heritage is not linked to the fact that it perpetually remains as unfamiliar architecture? Is not its strangeness, an obstacle to attachment, not grounded in the owners or inhabitants own behaviour, all too often treating their building simply as a utilitarian object, modifiable a infinitum, for reasons of practicality or taste? (...)" (Vanlathem, 2005, p.198). Modern houses cannot be seen as icons, they must be seen as houses to be lived in and adapted to nowadays life. However, having been constructed in big plots and located in natural reserve areas, they are an easy target of touristic speculation.

The quick mapping and registering of these houses is a necessary strategy to avoid touristic investments that don't regard their main architectural characteristics as modern examples. Classifying part of these houses as monuments is almost impossible and cannot be a solution for the problem. However, mapping their existence and highlighting their architectural interest can avoid the demolition or adulteration. Adapting these houses for modern life requirements is a necessary task for the actual generation of architects. According to Alexandra Teague (2005) “(...) how should modern buildings be remembered? As aesthetic and idealised objects, or as places created in which people live work and play? (...)" (Teague, 2005, p.223).

This is the main issue that these houses face: Will they remain as family houses or will they be replaced by "modern museums"? One of the possible solutions for big family houses, such as José Soares house, is their transformation into guest houses. Maintaining the vintage charm of the decade of 1960 can be a catch to attract clientele. According to Marieke Kupiers (2005) “ (...) Modern Monuments no longer can be used in its original form and function. At least one of both 
should be adapted to make the building fit the future again, due to new building codes, new technical requirements (...)" (Kupiers, 2005, p.209). The program of the holiday house is assumed as the research laboratory of the "third way" in modern Portuguese architecture. Architects have to explore this legacy and find new concepts of use for such an important testimony.

\footnotetext{
$1 \rightarrow$ "As imposições que regulamentam a instalação de construções na zona em questão, não permitindo que se façam trabalhos de alvenaria obrigou a que se procurassem rochas firmes para o assentamento das colunas" translated by the author, from portuguese edition in "Casa de férias, Arrábida" in Revista Binário, Lisboa, No59, Maio 1963, pp.480-482.

$2 \rightarrow$ "criou-se uma obra válida, não só pela sua sinceridade construtiva como pela compartimentação, funcionamento e valorização humana dos ambientes internos e externos. Aliás, o espaço exterior participa da vida da própria casa, especialmente o prolongamento da sala de estar, verdadeiro páteo abrigado dos ventos predominantes, defenido pelos dois corpos da casa e pela ligeira duna que - limita do lado do rio" translated by the author from the portuguese edition in "Casa de Ofir" in Revista Arquitectura, Lisboa, N59,1957, pp.13.
}

\section{Bibliography}

Almeida, P. (1996). Viana de Lima. In Armando Secca (eds). Viana de Lima, arquitecto 1913-1991 (pp.82). Porto.

Boyer, M. (1995). L’'Invention du tourisme, Paris, Gallimard.

Briz, M. (2003). A Veligiatura Balnear Maritima em Portugal (1870-1970): Sociedade Arquitectura e Urbanismo, Ph.D. thesis, Lisboa, FCSH, Universidade Nova de Lisboa.

-

Cazes, G. (1992). Fundaments pour une geographie du tourisme et des loisirs, Paris, Bréal.

-

Fernandez, S. (1988). Percurso: arquitectura portuguesa: 1930-1974, Porto, FAUP publicações.

-

Kupiers, M. (2005). Fairy Tales and fair practice, Considering Conservation, Image and Use. In Jean Yves Andrieux, Fabien Chevalier (eds.). La reception de l'architecture du movement modern: Image, Usage, Heritage (pp. 207-214). Saint Etienne: Saint Etienne Université.
Lobo, S. (2012). Arquitectura e Turismo: Planos e Projectos, as cenografias do lazer na costa Portuguesa da $1^{a}$ República à Democracia, Ph.D. thesis, Coimbra, DAFCTUC.

Ramos, R. (2010). A casa, Arquitectura e Projecto doméstico na primeira metade do século XX Português, FAUP publicações, Porto.

Teague, A. (2005). Rose Seidler House: the Representation of use Value in Modern Places. In Jean Yves Andrieux, Fabien Chevalier (eds.). La reception de l' architecture du movement modern: Image, Usage, Heritage (pp. 219-223). Saint Etienne: Saint Etienne Université.

Tostões, A. (1997).Os Verdes anos na Arquitectura Portuguesa dos anos 50, Porto, FAUP publicações.

-

Tostões, A. (2000). Casas de Férias modernas, anos 50 e estilo contemporâneo- A utopia de uma doce vida In Jornal de Arquitectos, No 196 (pp.45-53), Lisboa, Ordem dos Arquitectos.
Vanlaethem, F. (2005). Heritage and Conservation Strategies. In Jean Yves Andrieux, Fabien Chevalier (eds.). La reception de l'architecture du movement modern: Image, Usage, Heritage (pp. 197-199). Saint Etienne: Saint Etienne Université.

Arquitectura, "Casa de Ofir", Lisboa, No59,1957.

-

Binário, "Casa de férias, Arrábida" Lisboa, N59, Maio 1963, pp.480-482. 